\title{
PENGARUH MOTIVASI BELAJAR DALAM MENINGKATKAN PRESTASI SISWA
}

Oleh:

\section{Rosimah Lubis}

\begin{abstract}
Dengan motivasi yang kuat itulah akan menimbulkan aktivitas belajar yang tinggi pula bagi murid-murid. Dengan gambaran ini jelas pula bahwa motivasi mempunyai pengaruh yang besar terhadap prestasi belajar murid. Tinggi rendahnya prestasi dapat pula ditentukan oleh besar kecilnya motivasi seseorang untuk belajar.Prestasi adalah keadaan lebih baik dari pada diri seseorang dibandingkan dengan orang lain. Misalnya seorang siswa dapat dilihat prestasinya melalui perbandingan dengan teman lain yang sekelas. Biasanya dengan adanya perbandingan tersebut siswa lebih terdorong untuk mencapai prestasi yang baik.
\end{abstract}

Keywords: Motivasi belajar, prestasi siswa 


\section{Pendahuluan}

Istilah belajar sebenarnya sudah merupakan istilah yang umum dipergunakan oleh masyarakat dalam setiap kesempatan. Istilah belajar ini juga selalu dikaitkan dengan mengajar atau dengan kata lain kegiatan belajar itu dapat dijumpai andaikata ada kegiatan mengajar. Hal ini menimbulkan asosiasi kepada sekolah seolah-olah belajar itu hanya ada sekolah saja. Atau pengertian yang lebih maju sedikit adalah belajar di rumah untuk menyelesaikan pelaran-pelajarannya dengan kegiatan murid di sekolah. Pengertian yang demikian adalah belajar dalam arti yang sangat sempit atau disebut menurut pandangan tradisional.

Sebenarnya dalam pengertian yang lebih lebih luas ialah segala aktivitas manusia yang bertujuan untuk menambah ilmu pengetahuan dan keterampilan, maka belajar tidak teratas di bangku sekolah formal tetapi juga dari pengalamanpengalaman kerja atau di dalam masyarakat. Jadi orang dapat juga belajar dari pengalaman. Untuk lebih jelasnya tentang pengertian belajar ini penulis mengemukakan pendapat: "Belajar adalah suatu kegiatan anak didik dalam menerima, menanggapi serta menganalisis bahan-bahan pelajaran yang disajikan oleh guru yang terakhir pada pada kemampuan anak menguasai bahan pelajaran yang disajikan itu". ${ }^{1}$

Pengertian di atas mengkhususkan belajar sebagai kegiatan anak didik, apakah murid, siswa, mahasiswa atau peserta suatu kursus. Sehubungan dengan pelajaran yang diberikan oleh guru. Belajar berakhir setelah tujuan yang ingin dicapai oleh guru atau lembaga pendidikan tempat itu anak belajar. dengan demikian belajar yang dikemukakan di atas masih berkisar belajar dilembaga pendidikan yaitu belajar dalam kegiatan sebagai anak didik dan kalau ada anak didik tentu ada pula pendidik dan tujuan pendidikan. Jadi pengertian ini tidak mencakup pengertian belajar tanpa orang yang mengajarkan atau belajar sendiri. Hal ini dapat mengandungpertanyaan apakah yang dimaksud dengan belajar?

Belajar adalah kegiatan anak didik semata-mata dan belajar oleh orangorang yang membentuk tingkah laku atau menambah ilmu pengetahuan tanpa melalui prosesnya tidak dapat dikatakan belajar. belajar yang dimaksud atas masih dibatasi pada belajar di lembaga pendidikan formal dan non formal tidak tercakup di lembaga pendidikan in formal.

Bertitik tolak dari prinsip pendidikan seumur hidup (long life education), maka pengertian belajar bukan hanya kegiatan anak didik dalam menguasai bahan

${ }^{1}$ M. Arifin, M. Ed, Hubungan Timbal Balik di Lingkungan Sekolah dan Keluarga (Jakarta: Bulan Bintang, 1997), hlm. 161-163. 
pelajaran yang diberikan oleh guru saja. Tetapi seluruh kegiatan manusia untuk menambah pengetahuan dan keterampilan sudah dikatakan belajar. hal ini ada kaitannya dengan tujuan belajar yaitu: "belajar diajukan pada: Pengumpulan pengetahuan, Penanaman konsep dan kesehatan, serta, Pembentukan sikap dan perbuatan."

Kalau belajar diajukan untuk mendapatkan hal-hal tersebut diatas, maka belajar tidak hanya terbatas hanya dalam ruang belajar. akan tetapi belajar juga berarti sebagai kegiatan yang diidentikkan yang sambil lalu, belajar adalah suatu proses yang menuntut adanya perubahan tingkah laku dan pola berfikir.

Berdasarkan uraian tersebut di atas dapat diambil kesimpulan bahwa belajar itu mempunyai arti yang luas dan sempit. Seperti yang dikemukakan bahwa “ pengertian belajar itu dibagi kepada dua jenis pandangan, yaitu pandangan tradisional dan pandangan modern". ${ }^{3}$

Jadi belajar menurut pandangan tradisional adalah: "usaha memperoleh sejumlah ilmu pengetahuan". Pengetahuan dalam hal ini mendapat perhatian penting. Sedangkan pandangan modern belajar adalah: "proses perubahan tingkah laku berkat interaksi dengan lingkungan". Dari pandangan ini proses belajar bukan hanya sasarannya kepada ilmu pengetahuan, tetapi dalam perubahan ini lebih mengarahkan pengertian belajar dalam arti yang sempit.

Demikian pula dengan hasil prestasi belajar yang dimaksud adalah prestasi belajar menambah atau mengumpulkan pengetahuan tanpa melalui proses pendidikan formal dan non formal. Prestasi belajar sebagai hasil sktifitas anak didik/siswa dalam mengumpulkan pengetahuan di bawah bimbingan guru, dilihat dari hasil tes atau sitim evaluasi.

Mencapai suatu hasil dalam kegiatan belajar merupakan prestasi yang dicapai dalam kegiatan belajar anak. Prestasi belajar anak dapat dilihat melalui perbandingan dengan prestasi dari teman belajar lain.

Prestasi adalah keadaan lebih baik dari pada diri seseorang dibandingkan dengan orang lain. Misalnya seorang siswa dapat dilihat prestasinya melalui perbandingan dengan teman lain yang sekelas. Biasanya dengan adanya perbandingan tersebut siswa lebih terdorong untuk mencapai prestasi yang baik.

Jadi arti dan makna dari prestasi belajar adalah taraf yang dicapai anak selama mengikuti proses belajar. Hal ini ialah untuk mendorong atau merangsang

${ }^{2}$ Winarno Surachmad, Administrasi Pendidikan (Jakarta: PT Aries Kina, 1986), hlm. 49.

${ }^{3}$ Oemar Hamalik, Media Pendidikan (Bandung: Alumni, 1985), hlm. 54. 
siswa supaya berusaha dan belajar lebih baik sehingga akan memperoleh prestasi yang lebih tinggi dari prestasi sebelumnya.

Oleh sebab itu maka prestasi itu diukur berdasarkan usaha optimal seseorang, yang hal ini tergantung kepada kemampuan seseorang berusaha. Jadi usaha itu cukup menentukan diri seseorang dalam mencapai sesuatu sebagaimana Allah SWT telah berfirman dalam surat Al Rad ayat 11:

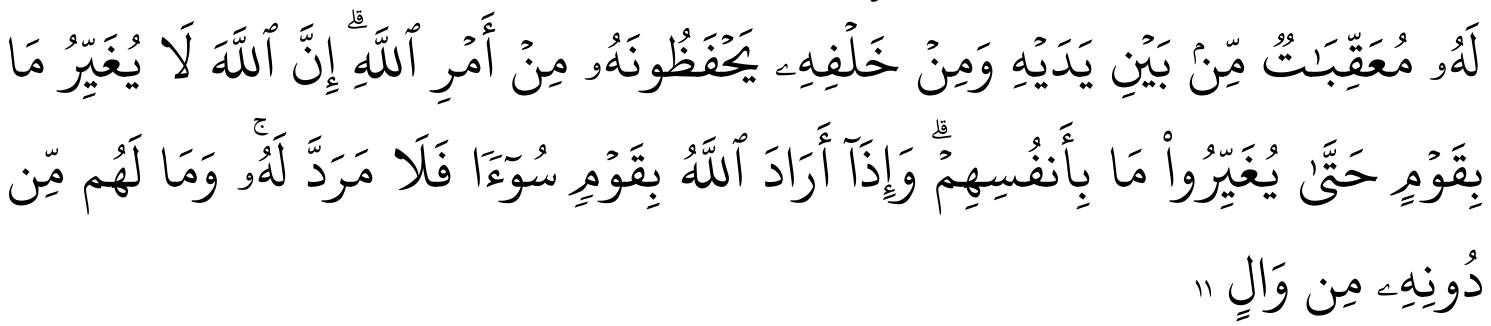

11. Bagi manusia ada malaikat-malaikat yang selalu mengikutinya bergiliran, di muka dan di belakangnya, mereka menjaganya atas perintah Allah. Sesungguhnya Allah tidak merubah keadaan sesuatu kaum sehingga mereka merubah keadaan yang ada pada diri mereka sendiri. Dan apabila Allah menghendaki keburukan terhadap sesuatu kaum, maka tak ada yang dapat menolaknya; dan sekali-kali tak ada pelindung bagi mereka selain Dia

Bagi tiap-tiap manusia ada beberapa Malaikat yang tetap menjaganya secara bergiliran dan ada pula beberapa Malaikat yang mencatat amalan-amalannya. dan yang dikehendaki dalam ayat ini ialah Malaikat yang menjaga secara bergiliran itu, disebut Malaikat Hafazhah. Tuhan tidak akan merobah Keadaan mereka, selama mereka tidak merobah sebab-sebab kemunduran mereka.

Jelaslah prestasi yang baik diperoleh seseorang itu merupakan usaha yang dilakukan sebelumnya. Begitu juga keadaan prestasi yang kurang dimiliki oleh anak juga merupakan hasil penilaian yang dilakukan melalui kegiatan evaluasi belajar. Hasil tersebutlah dijadikan standar kemampuan memproduksikan kembali pelajaran yang telah ditetapkan. Kategori-kategori prestasi murid biasanya dikelompokkan kepada prestasi sangat baik, baik, cukup dan kurang. Prestasi sangat baik dipeoleh siswa bila nilai ujiannya berada diantara nilai 81 sampai 100, niali sedang antara 71 sampai 80, nilai cukup antara 61 sampai 70 sedangkan prestasi kurang apabila siswa memperoleh nilai antara 51 sampai 60 .

Arti dan makna prestasi belajar adalah taraf pencapaiannya sendiri sesudah ia mengikuti proses belajar atau dengan taraf pecapaian hasil belajar siswa. Dan makna yang lebih jauh daripada prestasi belajar ialah mendorong atau merangsang 
siswa untuk berusaha dan belajar lebih baik sehingga akan memperoleh sukses yang lebih tinggi.

\section{Motivasi Belajar dan Pengaruhnya terhadap Belajar}

Motivasi diangkat dari kata motif yang mengandung pengertian Faktor-faktor yang merangsang sesuatu. Motif itu merupakan: sesuatu yang melengkapi suatu penggerak, alas an-alasan atau dorongan-dorongan dalam diri manusia yang menyebabkan ia berbuat sesuatu.

Pengertian diatas menunjukkan bahwa motif merupakan jawaban dari pertanyaan "kenapa". Kenapa murid-murid itu sekolah, karena disuruh orang tua atau karena ingin pandai dan lain-lain. Jawaban tersebut merupakan motif-motif murid itu untuk sekolah. Jadi yang dimaksud dengan motivasi belajar adalah: "Kekuatan-kekuatan atau tenaga-tenaga yang dapat memberikan dorongan kepada kegiatan belajar murid". 4

Kesungguhan belajar dapat ditentukan oleh kuatnya motivasi itu. adapun motivasi yang kuat yang dimaksudkan itu adalah motivasi yang bukan merupakan proses pemaksaan, tetapi lahir dari suatu kebutuhan. Hal ini sesuai dengan pendapat yang dikemukakan oleh Winarno Surachman bahwa: motivasi yang mempunyai daya penggerak yang besar adalah motivasi yang bersifat intrinsik. ${ }^{5}$

Motivasi intrinsik ialah mptivasi yang hakiki, sedangkan motivasi yang hakiki adalah yang berdasrkan kepada kebutuhan hidup manusia yang berarti tumbuh dari dalam sebagai suatu kebutuhan, bukan dipaksakan dari luar. Maka motivasi intrinsic adalah motivasi yang berasal dari diri anak sendiri. ${ }^{6}$

Dengan motivasi yang kuat itulah akan menimbulkan aktivitas belajar yang tinggi pula bagi murid-murid. Dengan gambaran ini jelas pula bahwa motivasi mempunyai pengaruh yang besar terhadap prestasi belajar murid. Tinggi rendahnya prestasi dapat pula ditentukan oleh besar kecilnya motivasi seseorang untuk belajar.

Sebagaimana telah dikemukakan di atas bahwa motivasi yang murni adalah motivasi yang bukan merupakanpaksaan, karena hal it kesadaran akan tujuan itu timbul pula minat terhadap belajar sehingga timbullah tindakan yang disebut proses belajar. motivasi yang demikian inilah yang mempengaruhi proses belajar.

${ }^{4}$ Amir Daien Indrakusuma, Pengantar Ilmu Pendidikan (Jakarta: Usaha Nasional, 1973), hlm. 162.

${ }^{5}$ Winarno Surachmad...hlm. 51.

${ }^{6}$ Amir Daien...hlm. 162. 
dengan demikian jelaslah tinggi rendahnya prestasi belajar seseorang ditentukan oleh besar kecilnya motivasi itu.

\section{Pengaruh Minat terhadap Hasil Belajar Belajar}

Belajar adalah proses perubahan diri manusia, bila sesudah selesainya suatu usaha belajar tidak terjadi perubahan dalam diiri manusia tersebut, maka tidaklah dapat dikatakan bahwa padanya telah berlangsung proses belajar. Tentu saja yang diinginkan agar perubahan yang terjadi dalam diri siswa dalah perubahan yang berencana dan bertujuan.

Terjadinya hasil belajar yang baik sangat ditentukan oleh perhatian dan minat siswa/anak dalam belajar. kehendak atau kemauan erat dengan hubungannya dengan minat yang dimiliki, karena minat mengarahkan timbulnyatimbulnya kehendak seseorang. Apabila perhatian dan minat anak terpusat pada pelajaran, maka pelajaran itu akan ditangkap dan dicerna serta segala sesuatu yang berhubungan dengan pelajaran tersebut dapat diketahui dengan mudah.

Apabila minat atau perhatian anak cukup besar terhadap pelajaran, maka hasilnyapun akan cukup baik. Memperhatikan berarti memusatkan dan menyalurkan kemampuan-kemampuan belajar anak pada suatu soal. Jiwa anak menjadi waspada, pengetahuan yang sudah ada dalam dirinya dapat dirangkaikan dengan pengetahuan yang bahan baru menjadi suatu integrated.

Proses belajar akan lebih lancar dan mencapai prestasi yang baik, bila sianak belajar dapat senantiasa menetapkan kemaunnya dan kedudukannya dalam usaha belajar itu. Hal ini berarti bahwa cara-cara belajar yang sebaik-baiknya ialah senantiasa menilai, mengukur dan menerapkan tarap pencapaian tujuan atau maksud seseorang untuk belajar proses itu kerah kematangan social.

Situasi belajar terutama dipengaruhi oleh minat serta perhatian anak dan adanya tujuan atau maksud tertentu dari pihak yang belajar dan tujuan pada akhirnya membawa perubahan dalam diri pelajar kearah kematangan social.

Usaha belajar akan berlangsung secara efesien bila mana anak berada dalam studi yang merangsang perkembangan kalau diperhatiakan secara keseluruhan betapa komplitnya Faktor-faktor yang berpengaruh kepada proses dan prestasi belajar seseorang.

Faktor-faktor yang sangat menentukan adalah minat anak dalam memperhatikan prestasi belajar. namun demikian semua Faktor yang mempengaruhi pretasi belajar harus mendapatkan perhatian atau ikut serta diperhitungkan. Bila ingin membentuk proses belajar yang efektif dan efesien atau bila kita ingin mempunyai prestasi yang baik dari anak didik. Selain dari Faktor 
minat banyak lagi Faktor-faktor lain yang mempengaruhi proses dan prestasi belajar.

\section{Pengaruh Orang Tua dan Guru bagi Pestasi Belajar}

Sikap orang tua menghadapi anak di rumah tangga harusnya lebih banyak mencurahkan perhatiannya untuk mendidik karena:

"Keluarga memegang peran sangat penting dalam kemajuan dan kemakmuran suatu negara. Pada keluarga terletak kewajiban pertama untuk mendidik seseorang menjadi sehat, beradap, tahu sopan santun, mempunyai sifat-sifat yang baik dan menjadi anggota masyarakat yang cukup dan berguna. Keluarga juga menjadi pangkal seseorang menjadi tidak sopan, tidak beradap, pengganggu keamanan, perusak keamanan, perusak ketertiban, dan mengacau dalam masyarakat". 7

Ada orang tua yang bersifat lunak dan ada orang tua yang bersifat keras terhadap anaknya. Ada yang bersifat tidak mau dan a orang tua yang ingin pada semua urusan anaknya. Kesemua sifat itu ada baiknya dan ada buruknya, tergantung kepada watak dan tingkah laku anak yang dihadapi. Yang jelas kebutuhan anak itu harus diketahui orang tua baik dari sudt organis, atau psycologis untuk membimbing perkembangan watak anak.

Demikian juga halnya dengan guru bukan semata-mata mengajar saja tetapi aknya. guru harus mengerjakan berbagai hal yang bersangkut pauk dengan pendidikan anak didiknya. Fungsi sekolah berkewajiban mengembangkan bakat anak didiknya, kegemarannya, perasannya serta aspek-aspek kejiwaan lainnya.

Dengan bimbingan yang efektif yang dilakukan orang tua dirumah pada anaknya, menggunakan waktu belajar anak akan berkembang dengan baik untuk mencapai puncaknya.

\section{Penutup}

Kesungguhan belajar dapat ditentukan oleh kuatnya motivasi itu. adapun motivasi yang kuat yang dimaksudkan itu adalah motivasi yang bukan merupakan proses pemaksaan, tetapi lahir dari suatu kebutuhan. Hal ini sesuai dengan pendapat yang dikemukakan oleh Winarno Surachman bahwa: motivasi yang mempunyai daya penggerak yang besar adalah motivasi yang bersifat intrinsik.

Motivasi intrinsik ialah mptivasi yang hakiki, sedangkan motivasi yang hakiki adalah yang berdasrkan kepada kebutuhan hidup manusia yang berarti tumbuh

\footnotetext{
${ }^{7}$ Aisyiah Dahlan, Membina Rumah Tangga Bahagia dan Peran Agama dalam Rumah Tangga (Jakarta: Jenmars, 1969), hlm. 32.
} 
dari dalam sebagai suatu kebutuhan, bukan dipaksakan dari luar. Maka motivasi intrinsic adalah motivasi yang berasal dari diri anak sendiri. Dengan motivasi yang kuat itulah akan menimbulkan aktivitas belajar yang tinggi pula bagi murid-murid. Dengan gambaran ini jelas pula bahwa motivasi mempunyai pengaruh yang besar terhadap prestasi belajar murid. Tinggi rendahnya prestasi dapat pula ditentukan oleh besar kecilnya motivasi seseorang untuk belajar.

\section{Referensi}

Aisyiah Dahlan, Membina Rumah Tangga Bahagia dan Peran Agama dalam Rumah Tangga, Jakarta: Jenmars, 1969.

Amir Daien Indrakusuma, Pengantar Ilmu Pendidikan, Jakarta: Usaha Nasional, 1973.

M. Arifin, M. Ed, Hubungan Timbal Balik di Lingkungan Sekolah dan Keluarga, Jakarta: Bulan Bintang, 1997.

Oemar Hamalik, Media Pendidikan, Bandung: Alumni, 1985.

Winarno Surachmad, Administrasi Pendidikan, Jakarta: PT Aries Kina, 1986. 